\title{
Asking and answering: A contrastive study of English and Swedish basic communication verbs
}

\author{
Åke Viberg \\ Uppsala University, Sweden
}

\begin{abstract}
This article presents a contrastive study of the English verbs ask and answer and their Swedish correspondents based on data from the English Swedish Parallel Corpus (ESPC), which is bi-directional and contains Swedish and English original texts and their corresponding translations. As a background, a short overview is given of Verbal Communication Verbs (VCVs) in general with brief discussions of speech act theory (Searle), direct and reported speech and conceptual frames (FrameNet) and their syntactic realizations. The contrastive study is concerned with networks of polysemy and the relationships of various senses with differing syntactic realizations across languages. The senses of ask are primarily distributed between two verbs in Swedish: fråga 'ask a question' and be 'request (politely)' but even some verbs with more specific meanings are involved. The concept of answering forms a conceptual network which is similar in English and Swedish but contrasts with respect to the way meanings are divided up between various verbs. English has a number of verbs such as answer, reply, respond, correspond, retort and rejoin, whereas Swedish to a great extent relies on one verb (svara) and its morphological derivations: besvara, ansvara, motsvara, försvara. In the Conclusion, pedagogical applications of the study are briefly discussed.
\end{abstract}

Keywords: corpus-based contrastive study, lexical semantics, FrameNet, English, Swedish, Verbal Communication verbs

\section{Introduction}

This paper is one in a series of studies of Swedish Verbal Communication Verbs (VCVs) with a special focus on the most frequent verbs. In spite of the fact that there are around 400 Verbal communication verbs in the Swedish SUC-corpus (1 million words, mixed written genres), the most frequent verb säga 'say' accounts for $22 \%$ and the 10 most frequent verbs belonging to the field account for close to $50 \%$ of the textual occurrences of VCVs in this corpus. The most frequent verbs are also the most varied with respect to the range of constructions they can appear in and the patterns of polysemy that characterize them. An earlier study (Viberg 2016) analyzed verbs of saying, talking and telling based on the concept of the linguistic action scene (Dirven et al. 1982). This paper will present a case study of verbs 
of asking and verbs of answering. These two groups of verbs have been extensively described in English. Rudzka-Ostyn's (1989) study of ask accounts for a number of different meanings which are primarily distributed between two verbs in Swedish: fråga 'ask a question' and be 'request (politely)'. The wide network of meanings of the verbs of answering in English is described in (Rudzka-Ostyn 1995). In Swedish, the corresponding network is built around the verb svara 'answer' and its uses as a derived and prepositional verb.

The database for the earlier study and for the present one is the English Swedish Parallel Corpus (ESPC), which contains Swedish and English original texts and their corresponding translations making it possible to carry out a corpus-based contrastive study (Altenberg and Aijmer 2000, Electronic sources). The texts are divided into two broad genres: Fiction and Non-fiction with several subcategories. The original texts in each language comprise around 700,000 words relatively evenly distributed between the two genres. Following Johansson (2007), parallel corpora can be divided into translation corpora containing original texts and their translations and comparable corpora containing texts in two or more languages which are as similar as possible with respect to genre, time of production etc. The ESPC combines the functions of both these types of parallel corpora. The lexico-grammatical analysis of the verbs of asking and answering in English and Swedish will be based on the ESPC as a comparable corpus by extracting concordances of all the occurrences in original texts of each verb. In this way it is possible to identify a set of uses of each verb. (A use combines aspects of the meaning of the verb and the grammatical constructions in which it appears.) Only in a second step will the ESPC be used as a translation corpus by looking at the translations of each use. In this way, it is possible to make comparisons based on the translation patterns in combination with comparisons that are based exclusively on original texts in both languages.

The rest of the paper is structured in the following way. Section 2 gives a brief overview of VCVs in general. Section 3 is concerned with ask in its use to report questions and its Swedish correspondent fråga, whereas Section 4 describes the use of ask to report polite requests. Section 5 is concerned with be and other Swedish verbs used to express polite requests. Section 6 is devoted to the verbs of answering in English and Swedish and the semantic network that these verbs are connected to. The result of the study is summed up and discussed in Section 7 Conclusions.

\section{Verbal Communication Verbs: An overview}

\subsection{Reported speech}

The VCVs are primarily used to report speech. A sentence such as Peter told me to open the door involves two speech situations as shown in Figure 1. A primary speech situation where someone called Peter acts as Speaker and makes a request, for example Open the door! and a secondary speech situation, where a second speaker (the Reporter) reports the utterance made by the first speaker, for example Peter told me to open the door. The function of this sentence is to give information about what Peter said, not to make a request. 


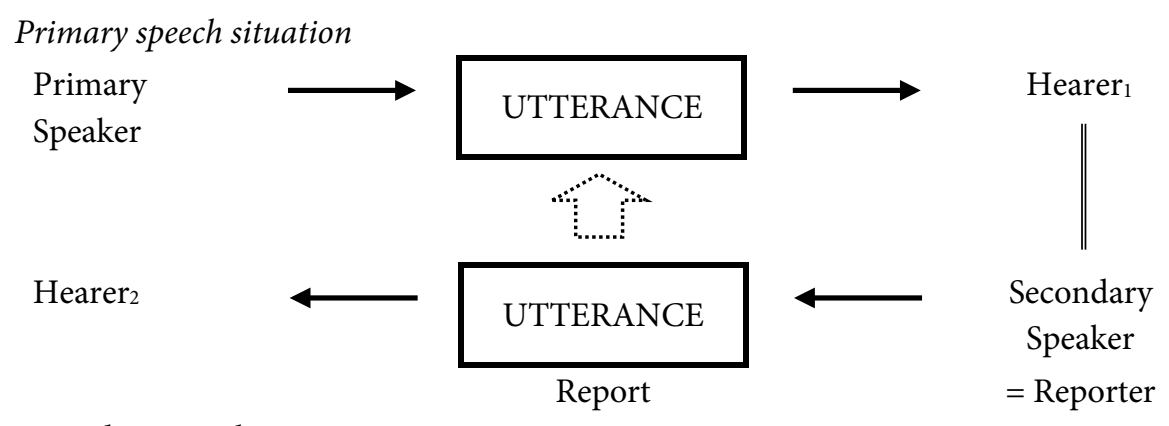

Secondary speech situation

Figure 1: Reported speech

The present paper will deal with speech act verbs used to report speech. Such reports can be direct and report the actual wording of the primary utterance or be indirect and report only the contents of the utterance in a more or less summary fashion. In English and Swedish, indirect report also triggers adjustments of tense and deictic markers which can follow different rules across languages and cause learning problems for second language learners (Hammarberg and Viberg 1976).

Since the terms direct and indirect are used also with reference to primary speech acts, the terms are compared in Table 1. A direct speech act has a form that explicitly expresses what kind of act it is, whereas an indirect speech act expresses this only implicitly, for example by using a question to make a request.

Table 1: Primary and reported speech acts

\begin{tabular}{ll}
\hline (PRIMARY) SPEECH ACTS & \\
\hline $\begin{array}{l}\text { Direct speech act } \\
\text { Indirect speech act }\end{array}$ & Open the door! \\
\hline REPORTED SPEECH (SECONDARY SPEECH ACTS) \\
\hline Direct report & "Open the door!” Peter said. \\
& "Can you open the door?” Peter said/asked. \\
Indirect report $\quad$ Clausal complement & Peter said that I should open the door. \\
& Peter asked me if I could open the door. \\
& Peter told me to open the door. \\
& Peter asked me to open the door. \\
Narrative report (condensed, non-clausal) & Peter asked me for help. \\
\hline
\end{tabular}

The term Narrative Report refers to cases where the speech act is realized in a condensed, non-clausal form. In this paper, the term will also refer to cases where a speech act fails to appear, as in: But she asked no questions about his past life and told him nothing about hers. (PDJ)

\subsection{Frame semantics}

The semantic description will be based on an eclectic combination of frame semantics and speech act theory. In frame semantics, verbs (and other relational words) evoke frames schematic structures of recurring situations (Fillmore 1982). Frame semantics is the 
theoretical foundation of FrameNet, a large lexical computerized database for English (see Fillmore et al. 2003). ${ }^{1}$ In FrameNet, the frame Communication is defined as follows: "A Communicator conveys a Message to an Addressee; the Topic and Medium of the communication also may be expressed." Communication is a general frame that covers any type of communication such as speaking, writing, signing or gesturing. In the following, reference will be made to a Speaker since only verbal communication will be described. (Speaker will also cover Writer in the few examples where it is relevant.) Table 2 shows the relationship between the conceptual frame and the canonical syntactic realization with some idealized examples. It should be noted that the syntactic realizations only show the realization of individual frame elements. In principle, word order and other aspects of clausal structure are regulated by the general grammatical system of the language.

Table 2: Verbal communication: From conceptual frame to syntactic frame

\begin{tabular}{|c|c|c|c|c|c|c|}
\hline Frame elements & Speaker & Linguistic action & Message & Addressee & Topic & Medium \\
\hline Syntactic & NP & Verb & NP & $\mathbf{P P}$ & PP & $\mathbf{P P}$ \\
\hline \multirow[t]{5}{*}{ Realization } & & & That-S & NP (object) & & \\
\hline & & & Wh-S & & & \\
\hline & Ann & said & a few words & to Peter & about it & over the telephone \\
\hline & Ann & asked & who was coming & & & \\
\hline & Ann & asked & & Peter & about it & \\
\hline
\end{tabular}

\subsection{Speech acts}

As discussed earlier for verbs of motion (Viberg 2015a,b), FrameNet needs to be complemented with a more detailed description of the semantic composition of the verb itself. Such a description is important to describe the semantic differentiation between verbs evoking the same frame and to characterize and explain several aspects of the patterns of polysemy of the verbs. For speech act verbs, a natural point of departure is Searle's (1976) classification of speech acts (or illocutionary acts as he called them), which has been further elaborated and applied to the analysis of German communication verbs in Harras et al. (2004, 2007) and in the contrastive study by Proost (2007).

Table 3 presents the major types of verbs used to report speech acts. The classification is based on Searle's (1976) classification, which has been criticized as a classification of direct speech acts, but serves as a good starting point for the lexical analysis. The verbs that will be analyzed in this paper are primarily used to report speech acts. Only in a few cases are they used to perform the act that the verb describes (i.e performatively). For example, Peter ordered Harry to come is not an order but a report that describes the content of Peter's utterance. The Reporter also performs a speech act, but that is rather what will be referred to as a Representative speech act. (The Reporter can also perform a request for information: Did Peter order Harry to come?)

Representative speech acts are used to describe the world and can be reported with two types of verbs: Assertive verbs, which report what is regarded as an opinion by the Reporter,

\footnotetext{
${ }^{1}$ The FrameNet database can be accessed at: http://www.icsi.berkeley.edu/ framenet/
} 
and Information verbs, which report information that the Reporter more or less accepts as a fact. If someone called Peter said: "The prisoners have escaped", this can be reported either with an assertive verb as Peter claimed that the prisoners had escaped or with an information verb as Peter told me that the prisoners had escaped. When tell is used, the reporter takes for granted that the information is correct (or at least the correctness is not regarded as an issue). By using claim, the Reporter signals that the information is regarded as an opinion (true or false) held by the primary Speaker.

Table 3: Verbs used to report Speech acts

\begin{tabular}{lll}
\hline Type of reported speech acts & Type of VCV & Verbs \\
\hline Representatives & Assertive verbs & claim, assert \\
& Information verbs & tell, inform \\
Directives & Directive verbs & ask, order, request \\
Commissives & Commissive verbs & promise, guarantee, vow \\
Expressives & Verbs expressing emotions & apologise, thank, rejoice, complain \\
& Verbs expressing evaluations & praise, criticize \\
Declarations & Declarative verbs & baptize, declare war, fire (from employment) \\
\hline
\end{tabular}

Directive speech acts are carried out in order to get the Addressee to do something and are reported by using verbs such as ask, order or request. Commissive speech acts commit the Speaker to do something in the future and are reported with verbs such as promise and guarantee. Expressive speech acts are said to express the Speaker's psychological state and are often realized as social routine utterances such as I'm sorry or Congratulations, Harry!, which can be reported as He apologised and He congratulated Harry. Declarations refer to speech acts that immediately change some institutional state of affairs if carried out by the right person in the right situation. Such verbs are often used performatively to carry out the act, for example You're fired! (or the canonical performative utterance: I fire you), but can also be used to report the act: NBC fires Donald Trump after immigration remarks (headline). ${ }^{2}$

There are some VCVs that do not report a specific type of speech act, for example the nuclear (most general) verb of the field say that can be used to report any type of speech act. Another feature that is not accounted for in Table 3 is the place of the speech act in the developing discourse. An important such feature is +/- Reactive (e.g. Proost 2007). Certain speech acts such as answer (see Section 6) and deny and reject presuppose an earlier speech act (such as a question or a claim or a proposal).

\section{Reporting questions in English and Swedish with ask and fråga}

If the English verbal communication verbs are ordered in descending frequency, ask comes third after say and tell. Ask has two major meanings, which have two separate major translations in Swedish: (a) request information, ask a question, translated with fråga and (b)

2 Perhaps baptize is a clearer example of an institutionalized, performative use of a declarative verb: “The requisite and sole valid form of baptism is: 'I baptize thee (or This person is baptized) in the name of the Father and of the Son and of the Holy Ghost."' (The Catholic Encyclopedia: http://www.newadvent.org/cathen/02258b.htm) 
a polite request, asking the Addressee to do something, translated with be. Table 4 gives a brief overview of the use of ask in the English Swedish Parallel Corpus (ESPC), which shows that ask in the sense 'ask a question' is practically three times as frequent in Fiction as in NonFiction. The two major senses of ask will be treated in the two following sections.

Table 4: The two major senses of ask in the ESPC

\begin{tabular}{lccccc}
\hline & Fiction $(\mathbf{F})$ & Non-fiction $(\mathbf{N F})$ & Total & Dominant Swedish translation \\
\hline Question & 307 & 103 & 410 & fråga & 322 \\
Polite request & 78 & 65 & 143 & be & 86 \\
Total & 385 & 168 & 553 & & \\
\hline
\end{tabular}

\subsection{The use of ask to report a question}

The first sense 'ask a question' ( $a k_{\mathrm{Q}}$ ) will be treated rather briefly in spite of the fact that it is the most frequent use, since English and Swedish are rather similar on this point. The uses of $a s k_{\mathrm{Q}}$ and their frequency of occurrence in the original English texts in the ESPC are summed up in Table 5 together with information about their Swedish translations.

Table 5: The uses of ask $k_{Q}$ and its major Swedish translations in the ESPC

\begin{tabular}{|c|c|c|c|c|}
\hline \multirow{2}{*}{$\begin{array}{l}\text { Type of Message } \\
\text { Direct report }\end{array}$} & \multicolumn{2}{|l|}{ English construction } & \multicolumn{2}{|l|}{ Swedish translations } \\
\hline & ask "X" & 191 & fråga “X” & 154 \\
\hline & & & säga “X” & 15 \\
\hline & & & undra "X" & 9 \\
\hline Indirect report & ask if-S, ask WH-S & 97 & fråga om-S, fråga WH-S & 86 \\
\hline (clausal) & & & undra 'wonder' om-S, WH-S & 3 \\
\hline Inner speech & ask oneself & 7 & fråga sig (Reflexive) & 6 \\
\hline Non-Clausal message & & 17 & fråga & 9 \\
\hline No message & & 47 & fråga & 40 \\
\hline \multicolumn{5}{|l|}{ Special uses of $a s k$} \\
\hline Support verb & ask a question & 37 & ställa en fråga 'put a question' & 27 \\
\hline \multirow[t]{4}{*}{ Rhetorical uses } & & 14 & & \\
\hline & may I ask & 3 & om jag får fråga / får jag fråga & 3 \\
\hline & if you ask me & 9 & om du vill veta (min åsikt...) & 5 \\
\hline & Other & 2 & & \\
\hline TOTAL & $a s k_{\mathrm{Q}}$ & 410 & fråga (Verb) & 298 \\
\hline
\end{tabular}

In almost half of the occurrences of $a s k_{\mathrm{Q}}$, the verb introduces a direct report as in (1). This is particularly characteristic of Fiction (F: 159, NF: 32). The dominant Swedish translation is fråga used in a congruent structure. In both languages, the Addressee is optional and realized as a direct object. ${ }^{3}$

3 In all examples from the ESPC corpus, the original version appears first followed by a text code, e.g. (DF1) in (1), the reference of which is listed on the homepage of the ESPC project (see Electronic sources). Literal translations and other comments are sometimes given within square brackets. The original text is provided on top, followed by the translation. That's why there is a switch when Swedish original texts are quoted. 
(1) “Is there anyone else here?" I asked her.(DF1)

"Finns det någon annan här?" frågade jag henne.

The second most frequent translation is the nuclear verb säga 'say'. This verb can be used to give a direct report of any type of speech act. In several of the examples - but not in all - säga is used when the question is rhetorical. In (2), the reported utterance is a reproach rather than a genuine question.

(2) "How could you do such a thing?" she asked Edward.(AT1)

"Hur kunde du bära dig åt på det viset?" sade hon till Edward.

Undra is rather a verb of thinking (I have always wondered what a sextant is), but like its English correspondent wonder, it can also be used as a VCV to translate ask. In (3) the Addressee is not translated since undra does not allow an explicit Addressee, which is a sign that it is not basically a communication verb. It is used conventionally together with direct and indirect reports of questions but expresses a request for information only implicitly by saying that the speaker wants to find out something. For that reason, wonder is often felt to be less intrusive than ask.

(3) What should we do? she asked me.(RDO1)

Vad ska vi göra? undrade hon. [wondered she]

The contrast between ask and wonder in its prototypical meaning can be seen clearly in examples such as (4), where wonder is used as a mental verb and forms an antonymous pair together with ask.

(4) Is she, perhaps, a vegetarian, Evelyn wondered, but did not like to ask, fearing the answer would be negative.(MD1)

Är hon kanske vegetarian, undrade Evelyn, men ville inte fråga av rädsla att svaret skulle bli nekande.

When ask is used to introduce an indirect report realized as a full if-S or Wh-S clause, fråga is completely dominant as a translation (see 5). Indirect reports are more frequent in Fiction than in Non-Fiction (F: 57, NF: 40), but the difference is not as great as it is with respect to direct reports. Undra 'wonder' is used as a translation only three times.

(5) I asked if by any chance Greville had made a will,(DF1)

Jag frågade om Greville händelsevis hade skrivit ett testamente,

There is a close relationship between VCVs and mental verbs. Think can be used to report direct and indirect thoughts with the same types of complements as say. With a reflexive object as in (6), ask refers to inner speech and is usually translated with the reflexive fråga sig. In this use, ask is not clearly a VCV any longer but rather a mental verb.

(6) "What's that?" he asked himself, and sneezed.(JC1)

"Vad är det här för någonting?” frågade han sig och nös. 
Only in few cases (17 in all), there is a non-clausal message. It can consist of a pronoun (Why did he ask that?, a quantitative (He asked a lot/He didn't ask anything) or a single question word (He only asked why).

In combination with the noun question, ask serves syntactically rather as a support verb (cf. give a speech). In most examples, the message is not expressed (see 7). The dominant translation is ställa en fråga 'put a question').

(7) The man would only speak to ask questions, and having gained the information he desired, he would fall silent again.(RL1)

Mannen yttrade sig bara för att ställa frågor /---/

In (7), no message is reported, so ask a question in this as in most examples functions as a speech activity verb like speak and talk (see Viberg 2016, Section 4). Like these verbs, ask a question freely takes an Addressee and a Topic: ask $\mathrm{sb}$ a question about sth. In addition to the majority of the examples with ask a question, there are 47 examples where there is no message. Ask by itself functions as a speech activity verb in many of the examples where there is no message but only a topic and in some cases - as in (8) - also an Addressee.

(8) You can talk French to him, and ask him about Iraq.(MD1)

Du kan tala franska med honom och fråga honom om Irak.

There are 12 examples where the topic is marked with the preposition about (usually corresponding to om in Swedish). In addition, there are 8 examples, where there is a topic without any marker, and this is an interesting option since there is no direct correspondence to this construction in Swedish. In (9), the topic marker om is simply inserted.

(9) She called Becky at the travel agency to ask his flight number,(AT1)

Hon ringde till Becky på resebyrån och frågade om flightnumret,

All examples with a Zero-marked topic are restructured in the Swedish translation. The simplest solution is to insert a topic marker as in (9) and in ask directions translated fråga om vägen ('ask about the way'), but in several cases a paraphrase is used: "Why do you ask my name?" (KAR1) Varför vill du veta mitt namn? ['Why do you want to know my name?'] All of the examples with a Zero-marked topic refer to specific information. Looking back at example (8) for comparison, it is obvious that a lot of different questions can be asked about Iraq. The examples where there is only a topic are included in the category No message in Table 5. In addition, there are examples where neither the message nor the topic is expressed. Actually, the only obligatory argument is the subject, but there are relatively few examples of this type. Often the message can be inferred from context, see (4) above, where the understood message of ask is related to the message of wonder in the preceding clause. Swedish and English are rather similar on this point. 40 of the 47 examples with no message are translated by fråga.

As will be discussed in Section 4, ask referring to a polite request has several interesting uses when it is combined with a spatial particle. There is only one such combination when ask refers to a question: ask round. This is an example of a condensed narrative report (see 
Table 1 above). In example (10), the Swedish translation is a set phrase containing the verb höra 'hear', which has several uses referring to active request for information (see Viberg 2008: 149-151).

(10) We'll be asking round the village, anyway.(MW1)

Men vi ska höra oss för $\boldsymbol{i}$ byn också. [hear us for in the village]

In practically all examples, $a s k_{\mathrm{Q}}$ is used to report a question. There are only a few examples where $a s k_{\mathrm{Q}}$ is used in a semi-performative way with a first person subject. Such examples are included in the category Rhetorical in Table 5 since they serve to modify and comment on the current utterance rather than to ask for information. In (11), the speaker does not wait for an answer to the question may I ask, which rather is used to signal an objection in this example.

(11) "What's wrong with watching the telly, may I ask?" the father said.(RD1)

“Och vad är det för fel med att titta på TV, om jag får fråga?” sa hennes pappa.

Like most of the rhetorical examples, may I ask is a set phrase. This particular phrase has a close correspondent in Swedish om jag får frågalfår jag fråga 'if I may ask' / 'may I ask'. Another rhetorical phrase is if you ask me, which is used as a kind of hedge to prepare the Addressee for controversial statements as in (12) or to add emphasis to what the speaker says as in (13) or express the speaker's confidence in what is said as in another example, where may I ask is translated jag är säker på 'I'm sure'.

(12) That, if you ask $\boldsymbol{m e}$, is the main pleasure of adultery.(FW1)

Om ni vill veta vad jag tycker så är det äktenskapsbrottets främsta njutning.

[if you want to know what I think]

(13) Too bloody long, if you ask $\boldsymbol{m e}$, he said.(DL1)

Alldeles för förbannat länge ska jag säga dig, sade han. [shall I say you]

Set phrases with a semi-performative or rhetorical function is characteristic also of other basic VCVs (cf. Viberg 2016, Section 3.4 on Swedish säga 'say').

A special characteristic of fråga and of several other Swedish VCVs is that the Addressee cannot be passivized. One possibility to translate sentences with the Addressee as a passive subject as in (14) is to use a compound form of fraga with till 'to' (basically a preposition marking a destination or a receiver).

(14) When Picasso was asked how he painted, he replied, "I do not seek, I find."(DM1)

När Picasso blev tillfrågad hur han målade, svarade han: “Jag söker inte. Jag finner.” [When Picasso became to-asked how...]

Another option is to use an active sentence as in (15), where an agent has been supplied from context and turned into a subject in the Swedish translation.

(15) I remember when he was asked what the principal crop of Thailand was and he answered transistor radios.(JB1)

Jag minns när en lärare frågade honom vad som var huvudnäringen i Thailand och han svarade transistorradior. [I remember when a teacher asked him what...] 


\subsection{The use of Swedish fråga to report a question}

Swedish fråga corresponds very closely to ask in the sense 'ask a question'. In no less than 325 cases (86\%), ask is used as the translation (see Table 6). There are a few cases where fråga is translated with a more specific verb referring to the requesting of information: inquire, (to) question and interrogate. Want to know (or hear) as translation of fråga signals the request for information implicitly - like undra 'wonder' discussed above. The distribution of uses is very similar to that of $a s k_{\mathrm{Q}}$ shown in Table 5 above. Direct report and (clausal) Indirect report dominate completely followed by uses where there is no message..

Table 6: The uses of Swedish fråga and its major English translations in the ESPC

\begin{tabular}{lcccl}
\hline Swedish & \multicolumn{4}{c}{ English translations } \\
\hline Type of Message: & N & ask & wonder & Other \\
\hline Direct report & 163 & 140 & 2 & say (8), inquire (1) \\
Indirect report & 113 & 100 & 2 & $\begin{array}{l}\text { want to know (4), question (1) } \\
\text { want to hear (1) }\end{array}$ \\
Inner speech & 16 & 9 & 6 & question (1) \\
Non-clausal & 6 & 5 & & \\
No message & 73 & 64 & 1 & inquire (3), interrogate (1) \\
Other & 8 & 7 & & \\
TOTAL & 379 & 325 & 11 & \\
\hline
\end{tabular}

There is one use of fraga as a particle verb worth noticing. In combination with the spatial particle ut 'out', fråga refers to repeated, more or less exhaustive questioning. This is reflected in translations such as question and interrogate (see 16 and 17).

(16) Hela kvällen frågade han $\boldsymbol{u}$ t mig, hur jag hade kommit fram till mina slutsatser; om det fanns andra som tänkte som jag, och en massa andra saker i samma stil.(BL1)

He questioned me all evening, asked me how I had come to my conclusions, if there were other people who thought the way I do, and a lot of other things like that.

(17) Nu började hon fråga ut Edla.(KE2)

She began to interrogate Edla.

Interestingly, fråga is sometimes translated with ask in combination with an infinitive construction that is characteristic of the use of ask as a request verb (see Section 4). In (18), the complement of fråga is constructed as an if-S clause that signals an indirect report of a question, whereas the complement of ask in the English translation is restructured as an infinitive that expresses an indirect request to do something.

(18) Berra dunkade mig i ryggen och frågade om jag ville berätta mera om mittpunktsnormalen.(PP1) [and asked if I wanted to tell more about NP]

Bert clapped me on the back and asked me to tell them a bit more about the perpendicular bisector.

Another example of a restructuring of a question into a request to do something appears in (19). The meaning of fråga efter pigplats [lit. 'ask after (a) position as maid'] is hard to describe but rather means 'ask if there was a position as maid'. If that is the correct 
interpretation, ${ }^{4}$ this is an indirect request in Swedish. The English translation as in the previous example is restructured and expresses a request to do something.

(19) - Tror du jag vill ha din doter i mitt kök, din skettlurka! sa gästgivarfrun när Sara Sabina Lans kom och frågade efter pigplats åt Edla.(KE2) [asked after a position as maid for Edla]

"How can you imagine I'd want your daughter in my kitchen, you filthbag!" was the answer Sara Sabina Lans got from Isaksson's wife when she came to ask her to take Edla into service.

Examples of this type show that there is a close relationship - and sometimes even an overlap - between the two major senses of ask.

\section{Ask used to report a request to do something}

English and Swedish both have a rather large number of directive verbs that report a request, but there is a basic pair of verbs that are used to report a polite versus an informal request. In English, the verbs ask and tell contrast in this way when they are combined with an infinitive complement, whereas Swedish uses the verb pair be and säga 'say' with an infinitive complement. As a background to the discussion of the many uses of ask as a request verb that will be presented in Section 4.2, the next section describes the contrast between ask and tell as a request verb, since this contrast appears to be basic.

\subsection{The report of polite versus informal requests}

When making a request, the Speaker wants the Hearer to know that the Speaker wants the Hearer to carry out a certain act specified in the Proposition (P) expressed in the Message. To report a request, the two basic VCVs tell and ask can be used in a special construction. In this function, ask refers to a polite request to do something, which the Hearer is not obliged to carry out, whereas tell refers to something the Hearer is obliged (or at least ought) to do. The obligation could be based on an obligation imposed by the Speaker in an informal way or based on general social conventions or be based on what is in the best interest of the Hearer (I told him to look out for the car). It may be noted that ask and tell typically correspond to different types of direct requests (cf. Rudzka-Ostyn 1989: 631). A sentence such as She asked me to open the window most accurately reports a request expressed as a question (Can you open the window?) or containing a politeness marker (Please, open the window!), whereas a blunt imperative (Open the window!) most accurately is reported with tell (She told me to open the window). In actual practice, there is a wide range of alternatives, but idealized examples of this type point in the right direction. In Swedish, the closest correspondent to tell as a request verb is the use of the most general (nuclear) VCV säga 'say' in combination with one of the stressed particles till or åt (derived from prepositions meaning 'to'), see example (20).

\footnotetext{
4 Another interpretation is that it represents a parallel to ask for as a request described in Section 4.2. In any case, the example shows the close relationship between a question and a request.
} 
(20) Then she told Mum to leave.(BO1)

Så sa hon till mamma att gå.

The closest equivalent of ask to report a polite request is the special request verb be as in (21).

(21) I asked her to look into some of the other boxes,(DF1)

Jag $\boldsymbol{b} \boldsymbol{a} \boldsymbol{d}$ henne titta i några av de andra lådorna,

The canonical structure used to report a request is shown in Table 7. PRO in the syntactic frame refers to the understood Agent of the infinitive clause and the index (j) shows that the action referred to in the message is controlled by the NP functioning as object of the request verb.

Table 7: The canonical syntactic realization of a reported request

\begin{tabular}{lllll}
\hline Frame elements & Speaker & Linguistic Action & Addressee & Message \\
\hline Syntactic frame 1 & $\mathbf{N P}_{\mathbf{i}}$ & Verb (Particle) & $\mathbf{N P}_{\mathbf{j}}$ & $\mathbf{P R O}_{j}$ to-VPinf $=>\mathbf{P R O}_{\mathbf{j}}$ att-VPinf \\
\hline & She & told & mum & to leave. \\
& Hon & sa 'till & mamma & att gå. \\
& $\mathrm{I}$ & asked & her & to look in the box. \\
& $\mathrm{Jag}$ & bad & henne & (att) titta i lådan. \\
\hline
\end{tabular}

That there is a close relationship between ask as a question and ask as a polite request can be observed in (22).

(22) She knocked on his door and asked if he would be kind enough to show her the famous bird.(RD1)

Hon knackade på och frågade om han ville vara så snäll och visa henne sin omtalade fågel.

It is conceivable that (22) might be a report of a speech act such as Would you be kind enough to show me the famous bird? Both in English and Swedish, this could have been reported also in the form of a request, which requires a shift to the verb be in Swedish: She asked him to show her the famous bird / Hon bad honom visa (henne) sin berömda fägel. There is also a very close relationship between the use of tell as an information verb and tell as a request. In (23), the English original text has a that-S complement that informs the Addressee what the speaker considers to be necessary to do signaled with a modal (must). The Swedish translation in this case has complement that is restructured into an infinitive complement of the type characteristic of requests.

(23) Now that he had gained for them the treasure of land, they were willing to begin listening to him when he told them that they must stop the practice of burning trees, which had been going on for thousands of years.(LT1)

/---/ när han sade åt dem att sluta bränna träd, [when he said to them to stop burn trees]

In English, it is possible to realize the message as an infinitive complement introduced by a question word (Wh) as in (24). This structure does not exist in Swedish and requires a restructuring of the complement into an att('that')-S complement containing a modal (usually a form of ska 'shall' with the past form skulle). 
(24) Even when he wasn't there, he'd tell her what to do in letters.(AH1)

Till och med när han inte var hemma skrev han och sade till henne vad hon skulle göra.

When this complement is used with ask it refers to a request for instructions or advice and fråga could be used in the Swedish translation: She asked him what to do $=>$ Hon frågade honom vad hon skulle göra 'She asked him what she should do')

The translation pattern of tell used as a request verb is less complicated than for ask and is summed up in Table 8. The corresponding use of ask will be summed up in the following section together with its many other uses as a request verb.

Table 8: The translation pattern of tell as a request verb

\begin{tabular}{lccccc}
\hline \multicolumn{7}{c}{ tell } & \multicolumn{4}{c}{ Swedish translations } \\
\hline Request Total & 52 & säga åt/till & be & uppmana & tala om för \\
tell NP to-VPinf & 44 & $21^{\star}$ & 6 & 2 & 0 \\
Tell NP Wh to-VPinf & 8 & 4 & 1 & 0 & 3 \\
\hline$\star$ ) Two restructured translations: att-S [ska], Wh-S [ska] & &
\end{tabular}

The use of säga till/åt in Swedish originals shows that tell is the most frequent correspondent, see Table 9.

Table 9: The translation pattern of Swedish säga 'till/'àt

\begin{tabular}{lcccccc}
\hline & säga till/åt & \multicolumn{6}{c}{ English translations } \\
\hline Request Total & 28 & tell & ask & instruct & say & Other \\
NP to-VPinf & & 10 & & 1 & & \\
Other & & 8 & 1 & & 3 & 5 \\
\hline
\end{tabular}

When säga till/åt has an infinitive complement it practically always reports a request and is translated with tell in a congruent structure. Sometimes a request is also reported in a full att ('that')-S clause as in (25).

(25) Han sa till mig att jag skulle skissa på tillbyggnaden.(CE1) [that I should sketch] He told me to sketch the extension.

In (26), säga till is translated simply with say. The that-S clause in this case does not tell the Addressee what to do, but describes what the Speaker wants in a way that by implication represents an indirect request not to disturb.

(26) - Jag sa ju till att vi inte ville bli störda, sa Björk.(HM2) [that we not wanted be disturbed]

"I said we shouldn't be disturbed," said Björk.

\subsection{The many uses of ask to report a request}

Rudzka-Ostyn (1989) distinguishes a number of interrelated senses organized into a schematic network around $a s k_{\mathrm{R}}$ - ask used to report a polite request. These are shown in Table 10. The letters will be used as a reference also in Table 11, which shows the frequency of the various senses of $a s k_{\mathrm{R}}$ and their major translations. 
Table 10: A network of meanings related to ask as a polite request verb (Rudzka-Ostyn 1989: 631-632)

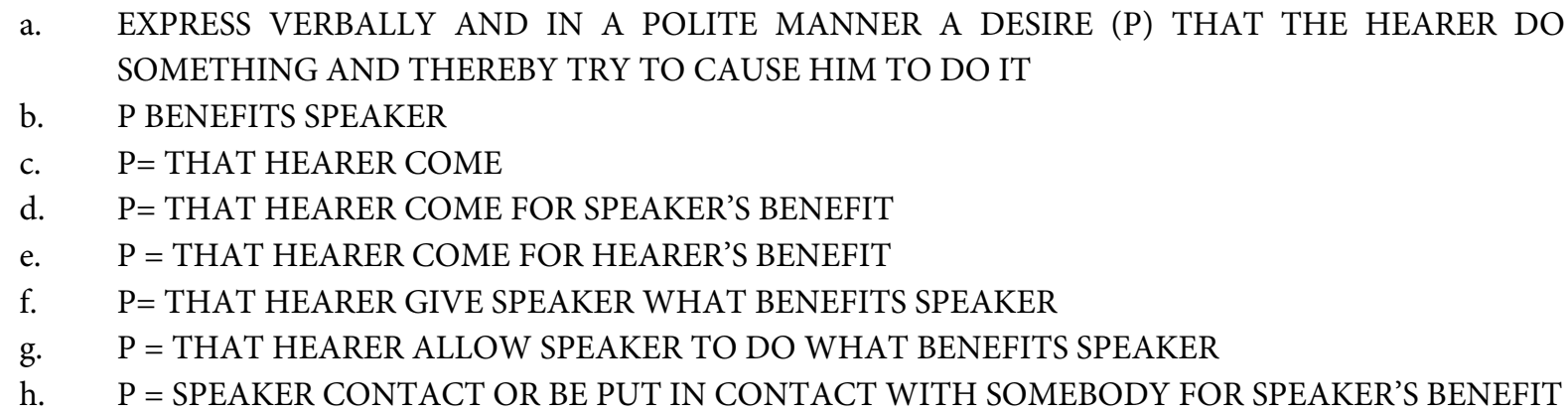

The general meaning, which is shared by all instances of $a s k_{\mathrm{R}}$, is described in (a). P refers to the proposition that describes the speaker's desire and in order to be a request the desire must be that the hearer should do something. This condition is fulfilled in most cases when the Message is realized as an object-controlled infinitive as described in the previous section. In the prototypical case (b), what is done benefits the Speaker. The most frequent Swedish translation is the verb be appearing in a congruent structure as in (27).

(27) Sometimes a woman would ask my father to "speak to" her husband.(NG1)

Ibland hände det att en kvinna bad min far "tala" med hennes man.

However, there are some clear examples such as (28), where the action does not benefit the Speaker. ${ }^{5}$

(28) I'll ask an officer to go out with you when we've finished.(MW1)

Jag ska $\boldsymbol{b} \boldsymbol{e}$ en polis gå med er dit ut när vi är färdiga.

Table 11 shows the frequency of occurrence of the senses of ask $k_{\mathrm{R}}$ and their Swedish translations. Senses (a) and (b) are presented together, since it is not always possible to decide from the concordance lines if what is to be done really benefits the Speaker. (Thus, "Benefit of Speaker" in the right column does not hold in an absolute sense, but refers to the typical interpretation.)

The rest of the senses refer to more fine-grained distinctions and are signaled by specific constructions. When the Message is condensed to for + NP (sense f), the desire is for the Hearer to give Speaker what benefits Speaker as in (29). The translation with the verb be uses a congruent structure with the preposition $o m+\mathrm{NP}-$ the same preposition that marks a Topic.

(29) At a junction I asked a food-seller for water.(BO1)

I en vägkorsning $\boldsymbol{b a d}$ jag en matförsäljerska om vatten.

5 The interpretation may be a little bit tricky. (28) does not report an act that benefits the Speaker or the Hearer ("an officer") of the speech act reported on (the primary speech act) but is an act that benefits a third party ("you"), which happens to be the Hearer of the report (the secondary speech act). 
Table 11: The senses of ask reporting a request and their major translations in the ESPC

\begin{tabular}{|c|c|c|c|c|}
\hline Meaning & Construction & $\mathbf{N}$ & Major translations & $\mathbf{N}$ \\
\hline \multicolumn{5}{|l|}{ POLITE REQUEST } \\
\hline \multicolumn{5}{|l|}{ Benefit of Speaker } \\
\hline \multirow[t]{2}{*}{ Polite request, general $(\mathrm{a}, \mathrm{b})$} & ask $\mathrm{NP}$ to $\mathrm{VP}_{\mathrm{inf}}$ & 70 & be NP (att) VPinf & 50 \\
\hline & & & be att-S & 1 \\
\hline \multirow[t]{2}{*}{ Ask to be given (f) } & ask for NP & 36 & be om NP / be att få NP & 20 \\
\hline & & & begära NPabstract (Formal) & 6 \\
\hline \multirow[t]{3}{*}{ Ask permission (g) } & ask to $\mathrm{VP}_{\text {inf }}$ & 10 & be att få VPinf & 4 \\
\hline & & & be om NP & 3 \\
\hline & & & anhålla/begära att få VPinf & 2 \\
\hline Ask for contact (h) & ask for NPhuman & 1 & be att få tala med NPhuman & 1 \\
\hline \multicolumn{5}{|l|}{ Benefit of Hearer } \\
\hline \multirow[t]{2}{*}{ Invitation (e, partly) } & ask NP Particle/ & 11 & bjuda Particle + NP/PP & 8 \\
\hline & ask NP to- $\mathrm{VP}_{\text {inf }}$ & & be NP VP inf & 2 \\
\hline Other & & 15 & be & 5 \\
\hline TOTAL & $\operatorname{ask}_{\mathrm{Q}}$ & 143 & be & 86 \\
\hline
\end{tabular}

Often what is asked for refers to an abstract concept (ask for advice / be om råd; ask for an interpretation / be om en tolkning). Related to this use are a few examples where what is asked for appears in the object slot: ${ }^{6}$ ask s.o.'s opinion, ask s.o.'s consent. In Swedish, the preposition cannot be left out: be om någons åsikt / be om någons medgivande. In one case, there is a paraphrase: he telephoned to ask my opinion translated han hade ringt mig för att fä ett råd '/---/ to get a (piece of) advice'

In (30), another verb begära is used in the translation. This verb takes an abstract noun referring to the desired action as an object: begära stöd 'demand support' and is used to report a formal requests.

(30) Montgomery himself must accept responsibility for one major Allied misfortune at this time: he asked for, and received, the support of the US First Army to secure his right flank.(MH1)

Han begärde och fick stöd av USA:s Första armé för att säkra sin högra flank.

In several examples, begära is combined with nouns referring to formalized procedures in institutional contexts: ask for an adjournment / begära uppskov; ask for a ruling / begära ett avgörande. There are also three non-literal uses where ask for is translated with rather colorless paraphrases: ask for it => vara vad någon förtjänar 'be what someone deserves' and ask for trouble > utsätta sig för 'expose oneself to (something bad)' orsaka besvär 'cause trouble'. A specialized verb is used also as a translation of ask for money / tigga pengar ('beg money' cf. tiggare 'beggar').

In the examples analyzed so far, the Speaker asks the Hearer to do something, but, actually both ask and be can be used when the Speaker wants the Hearer to give the Speaker permission to do something. In (31), the Message refers to an act by the Speaker.

\footnotetext{
${ }^{6}$ These examples are included in the category Other in Table 11
} 
(31) If I hadn't asked to speak to her, would you ever have told us she'd left you?(AT1)

Om jag inte hade bett att få tala med henne /---/

In examples of this type, ask does not have an object referring to the Addressee and the reference of the understood Agent of the infinitive is controlled by the subject of ask as shown with indexes in Table 12.

Table 12: Subject-controlled infinitive complements.

\begin{tabular}{lllll}
\hline Frame elements & Speaker & Linguistic Action & Addressee & Message \\
\hline Syntactic frame 3 & $\mathbf{N P}_{\mathbf{i}}$ & Verb & $\begin{array}{l}--- \\
(\mathbf{N P j})\end{array}$ & $\begin{array}{l}\text { PRO }_{\text {i }} \text { to-VPinf }=> \\
\text { PRO }_{\text {i att få VPinf }}\end{array}$ \\
\hline & $\mathrm{I}$ & asked & & to speak to her \\
& $\mathrm{Jag}$ & bad & $\begin{array}{l}\text { (honom) } \\
\text { 'him' }\end{array}$ & $\begin{array}{l}\text { att få tala med henne } \\
\text { to get speak with her }\end{array}$ \\
\hline
\end{tabular}

If there had been an explicit Addressee in English in example (31), there would have been a change of reference and the understood Agent in the Message would refer to the Addressee rather than the Speaker: I asked him to speak to her. In Swedish, there can be an explicit Addressee without any change in reference as long as $f a ̊$ appears in the infinitive complement: Jag bad honom att få tala med henne ('I asked him to get (to) speak to her'). In Swedish, the reference to the Speaker as Agent is expressed by using the verb få 'get' as a modal with permissive meaning ('be allowed'). If $f a ̊$ is left out, the Addressee (as in English) is interpreted as Agent: Jag bad honom att tala med henne 'I asked him to speak to her'. The restructuring can be illustrated with two examples from the same text. In Swedish, fă 'get' is used to ask permission as in (32).

(32) “May I examine it?” he asked,(OS1)

"Får jag undersöka det?” frågade han,

In the English novel from which this example is taken, the same speech act is reported as an indirect report of a question (33). The Swedish translation is restructured as an indirect report of a request.

(33) He asked if he might examine it,(OS1)

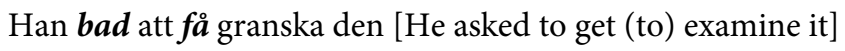

In (34), a similar example is translated into Swedish with a full om('if)-S structure. In that case, fråga must be used as a correspondent of ask.

(34) She asked if she might sit awhile and read a book.(RD1)

Hon frågade om hon fick sitta där en stund och läsa en bok.

When the NP refers to a person (sense h), the construction ask for NP can refer to the request that the Speaker be put in contact with someone as in (35). 
(35) She retrieved the telephone, dialled Learmouth Police Station and asked for Detective Sergeant Cooper.(MW1)

Hon lyfte telefonluren, slog numret till polisstationen i Learmouth och bad att få tala med kriminalinspektör Cooper.

The Swedish translation is restructured and uses the construction that expresses a request to be permitted to do something (be att få VPinf), in this case to speak to a certain person. Swedish can also use fragga with the preposition efter 'after' as in (36). This example shows how be and fråga in some cases can be used to express the same specific meaning of ask provided that the verb appears in a construction that is characteristic of the verb.

(36) Och där skulle hon fråga efter nån som hette Agnes Cecilia.(MG1)

When you get there, you should ask for someone by the name of Agnes Cecilia.

The use of narrative reports, where the message is presented in very condensed form, is characteristic of ask. There is a special construction, where ask is combined with a spatial particle or PP. Rudzka-Ostyn (1989) distinguishes three different senses of ask (c-e) when it appears in this construction, all containing the Proposition THAT HEARER COME (see Table 10). There are no examples in the corpus of the first two senses, but the most natural translation into Swedish appears to be the one expressing a polite request in general (be NP VPinfinitive), since be cannot appear in a congruent construction. See, for example, the translation shown in (37) of sense (d) - that hearer come for speaker's benefit.

(37) Ask the maid up. (Rudzka-Ostyn 1989: 630)

Be hembiträdet (att) komma upp ['Ask the maid to come up'] (My translation)

The most interesting of these senses is (e), which is exceptional since it refers to an action that is carried out to the Hearer's benefit. It is interesting also because a specific verb bjuda 'invite, offer, treat so to sth' is the most direct translation. This verb prototypically refers to something which is to the Hearer's benefit. It can also appear in the same construction as ask with a spatial particle or PP. In (38), the proposition refers to a wish for the hearer to come to a certain place (their home) and - as usually is the case with this construction - some activity connected to the place is referred to ('have supper') or implied (in some other examples).

(38) So this man and his wife, they asked the granny round for supper.(JC1)

Så den här mannen och hans fru bjöd in farmodern på lite kvällsmat.

[invited in the granny for ('on') a little supper]

Swedish bjuda can be combined with a spatial particle in a construction that is congruent with that of ask, but this is not possible with $b e$, which requires a restructuring to an infinitive construction, when it is used as a translation in (39).

(39) "You might have asked her in."(AT1)

"Men Macon, du kunde väl ha bett henne stiga in." [asked her step inside]

Semantically, be differs from bjuda by lacking the feature HEARER'S BENEFIT (category c in Table 10). If bjuda in had been used as a translation, it would have implied that the speaker 
would act as a host in some sense (for example, by showing her around or serving coffee). Example (40), taken from a book on the experience of Sweden from a foreigner's perspective, presupposes a traditional scenario where prospective dancing partners are sitting around the dance floor waiting to be asked to get up and dance.

(40) Once again the Swede met the challenge and asked the girl to dance.(JPM1)

Än en gång antog svensken utmaningen och bjöd upp flickan. [invited up the girl]

\section{The verb be and other Swedish directive verbs}

This section accounts for all the uses of be and bjuda and begära - the major correspondents of $a s k_{\mathrm{R}}$ - in order to see to which extent these verbs cover the same meanings as ask.

\section{1. be 'ask politely'}

As shown above, be corresponds to ask when that verb refers to a polite request. All the uses of be in the original Swedish texts in the ESPC are shown in Table 13 together with the English translations. The most frequent use is to report a polite request and in this case the dominant translation is ask. Direct reports occur only with low frequency and the same applies to indirect reports realized as that-S clauses. The most frequent realization of the Message is the Infinitive clause followed by the non-clausal realization be om NP 'ask for NP'. The pattern mirrors to a great extent what was found above for be as a translation of ask. Only in a few cases is a more special verb than ask used as a translation: pray, beg and urge.

Asking Permission to do something is a special case of polite request that has been singled out because it requires the use of $f a$ in the infinitive complement (see Table 12 above). There are some uses of be where ask is not used as a translation. One such use is referred to as Pray in Table 13 and occurs when be is used to report a prayer as in: Hon bad inte till Gud (MR1) translated She didn't pray to God. A topic can be introduced in the ordinary way with om: be om seger 'pray for victory'. When it refers to praying, be can also take a noun referring to a prayer as object; be bordsbön - say prayer or be used without any complement as in the following translation from English: He was praying. (RDO1) translated as: Han bad.

Another special use of be is to report an apology as in: morsan bad om ursäkt.(PP1), which is translated: Mum said she was sorry. In Swedish, this is just a special case of a condensed polite request using be om NP 'ask for' NP. Be om ursäkt can also be translated with the simple verb apologize (see 41).

(41) De gånger jag har träffat honom verkar han som om han bad om ursäkt för att han fanns till.(SW1) The times I've run into him, it always seems as if he wanted to apologize for simply existing.

There are also a few examples where be is used performatively. In (42), it is used to make an apology.

(42) - Jag ber om ursäkt, sa han.(HM2)

"I'm sorry," he said. 
Jag ber om ursäkt 'I ask for forgiveness' is the formula in Swedish corresponding to I'm sorry in English. Another performative use Får jag be om 'May I ask for' is a rather formal politeness marker. Example (43) appears in the context of a court hearing.

(43) - Får jag be om ert fullständiga namn. (MPC:HN) [may I ask for your full name] 'What is your full name, please?'

Table 13: The uses of Swedish be and its major English translations

\begin{tabular}{|c|c|c|c|c|}
\hline Meaning & Construction & $\mathbf{N}$ & Translation & $\mathbf{N}$ \\
\hline \multicolumn{5}{|l|}{ REPORT } \\
\hline \multicolumn{5}{|l|}{ Polite request } \\
\hline & Direct report & 2 & ask & 1 \\
\hline & & & say & 1 \\
\hline & Indirect report: Clausal & & & \\
\hline & be NP (att-)S & 4 & ask & 2 \\
\hline & & & pray & 2 \\
\hline & Infinitive complement & & & \\
\hline & NPi be NPj (att) PROj VPinf & 40 & ask & 34 \\
\hline & (att 13, Zero 27) & & urge (formal) & 3 \\
\hline & Narrative report & & & \\
\hline & be om NP & 19 & ask (for NP) & 13 \\
\hline & Message understood or pronominal & 6 & ask & 3 \\
\hline \multirow[t]{3}{*}{ Asking permission } & Infinitive complement & & & \\
\hline & NPi be (NPj) (om) att få PROi VPinf & 7 & ask & 5 \\
\hline & & & beg & 1 \\
\hline Pray & be (till Gud) & 8 & pray (to God) & 6 \\
\hline \multirow[t]{3}{*}{ Apology } & Narrative report & & & \\
\hline & be om ursäkt 'ask for forgiveness' & 4 & apologise, & 2 \\
\hline & & & say + sorry & 2 \\
\hline \multicolumn{5}{|l|}{ PERFORMATIVE } \\
\hline \multirow[t]{2}{*}{ Politeness marker } & & 4 & please & 2 \\
\hline & & & I pray & 1 \\
\hline Apology & & & I'm sorry & 1 \\
\hline TOTAL & be & 94 & ask & 58 \\
\hline
\end{tabular}

\section{2. bjuda 'invite', begära 'request'}

This section is devoted to the two verbs bjuda and begära that were used as translations of $a s k_{\mathrm{R}}$ besides be. As can be observed in Table 14, ask is not the most frequent translation of these verbs. Bjuda rather corresponds to offer and invite and begära to request. In order to describe the meaning of these verbs it is necessary to briefly discuss some of the major parameters that organize the contrasts between the directive verbs in general. As mentioned above, the distinguishing feature between be and bjuda is that the request refers to something that is, respectively, to the benefit of the Speaker or to the Hearer. Like ask, be and bjuda both 
are used when the right to impose an obligation on the Hearer is not taken for granted by the Speaker. That is, however, the case when verbs such as require and demand (Swedish kräva) are used. None of these presuppose any formalized or institutionalized social relationship or order-of-command between Speaker and Hearer such as the verb order. In Swedish, two different verbs are used that are based on different institutionalized roles. Beordra is used when there is an order-of-command (prototypically in the military) and beställa is used when the relationship between Speaker and Addressee coincides with that of Customer and Service provider ('to order goods or services').

Table 14: The major translations of bjuda and begära in the ESPC

\begin{tabular}{llll}
\hline bjuda & & begära & 39 \\
\hline Total & 54 & & \\
Major translations & & Major translations & \\
ask & 2 & ask & 8 \\
offer & 15 & request & 14 \\
invite & 13 & expect & 6 \\
& & demand & 3 \\
\hline
\end{tabular}

The most frequent translations of bjuda, offer and invite, both indicate that the Message describes something that is beneficial for the Addressee. (44) is one of the two examples translated with ask and are translated with a combination of ask and a spatial particle of the kind that was discussed in Section 4.2.

(44) Varför bjöd du $\boldsymbol{u} \boldsymbol{t}$ mej?(JG1)

Why did you ask me out?

Conceptually, bjuda is a blend of several types of verbs. It is a verbal communication verb, because an offer is presented verbally. In (44), the Addressee is asked to do something pleasant together with the Speaker (such as to go to a restaurant for a date). The translations of bjuda are interesting, since in many cases they require a partial reconceptualization combined with a restructuring on the grammatical level. In the English translation of (45), the Addressee is also asked to do something in a condensed form (to come over to someone's home). The argument marked with for indicates something that the Addressee will be given. In the Swedish version, bjuda has an argument marked with the preposition $p \stackrel{0}{a}$ 'on' corresponding to this argument. A literal translation would rather be: 'We have been offered afternoon coffee up at Percy's and Elsa's'. The request to go there is only implied.

(45) För vi är nämligen $\boldsymbol{b j u d n a ~ p a ̊ ~ e f t e r m i d d a g s k a f f e ~ u p p e ~ h o s ~ P e r c y ~ o c h ~ E l s a ( A R P 1 ) ~}$

'We've been asked over to Percy's and Elsa's for afternoon coffee.'

When this construction is used, bjuda partly is a verb of giving. This is reflected in an expression such as Jag bjuder 'It's on me' used when someone offers to pay the bill for the whole group. The argument marked with $p a ̊$ 'on' represents what is given and this is clearly reflected in the translation of (46), where the preposition to marks the corresponding argument in the translation. 
(46) Okej, jag bjuder på fika nånstans på Djurgårn.(JG1)

Okay, I'll treat you to coffee somewhere in Djurgården.

As a Verbal communication verb, bjuda is primarily used to present narrative reports with a condensed realization of the message. This applies as well to the cases where bjuda is translated with invite and offer (see 47 and 48).

(47) “Hörde du, torsken vill bjuda oss på middag!" meddelade hon glatt.(JG1)

"Did you hear that? The sucker wants to invite us to dinner!" she reported cheerfully.

(48) Främlingen $\boldsymbol{b j o ̈ \boldsymbol { d }}$ sen gubbarna $\boldsymbol{p a ̊ ~ v a r ~ s i t t ~ g l a s . ( S C 1 ) ~}$

Then the stranger offered the old men a drink.

Bjuda can also refer to a bid at an auction or to the offer to pay a certain sum for product in a business negotiation ('to say that one is willing to pay a certain sum for an object'). The verb then is used in the frame bjuda PRICE för GOODS, where the sum of money appears in the object slot as in the English translation with the verb offer in (49).

(49) Dom hade bjudit tjugofem kronor.(SC1)

They had offered twenty-five kronor.

In this particular use bjuda is in a converse relation to begära (like the pair 'buy' - 'sell'), since begära can take the Seller as subject: Peter begärde 100 dollar för cykeln - Peter asked \$100 for his bike. Be om - the usual correspondent to ask for - does not sound completely appropriate in this context, since - in addition to referring to a polite request - be has a relatively strong entreating component (like beg - but perhaps a little weaker. As mentioned, be can also refer to praying.) Begära suits better to refer to a negotiation between equal partners. As noted in Section 4.2, begära 'demand' is used as a translation of ask also in institutional settings, when begära is combined with an abstract noun (begära ordet 'ask to speak' / begära uppskov 'ask for a delay'). The most frequent translation of begära is the verb request (see Table 14 above), which is a polite but formal directive verb. In most cases, request is used as a translation of combinations of begära + abstract noun: begära skadestånd 'request compensation', begära upplysningar 'request information', begära klarläggnade 'request clarification'. Begära can also take a that-S clause as complement as in (50), but not an infinitive complement.

(50) Skyddsombudet kan också begära att en viss undersökning skall göras för kontroll av förhållandena inom skyddsområdet.(ARBM1)

The safety delegate can also request that a certain investigation be carried out to verify conditions within his safety area.

\subsection{Summing up the contrasts between ask and its Swedish correspondents}

Swedish divides up the linguistic functions covered by ask between the verb fråga, which reports questions, and be and some related verbs, which report requests. The lexical contrasts in Swedish have parallels in the choice of constructions both in Swedish and English. The verbs fråga and $a s k_{\mathrm{Q}}$ are frequently used with direct reports and clausal indirect reports, 
whereas $a s k_{\mathrm{R}}$ and be only in a few cases are used with these complements but typically are used with infinitive complements. In addition, the verbs (in particular when they refer to requests) are used in more or less lexicalized phrasal combinations as phrasal, prepositional or support verbs. Such combinations form less regular patterns but have meanings that can be related to the prototypical meanings of the verbs. There is a close semantic relationship between the functions of ask symbolized as $a s k_{\mathrm{Q}}$ and $a s k_{\mathrm{R}}$. This is reflected in the fact that indirect reports of questions sometimes are restructured as indirect reports of requests in the translations (see examples 18, 19 and 33 above) owing to the use of questions to express polite requests.

\section{The verbs of answering}

The verbs of answering are the major example of reactive verbal communication verbs, i.e., verbs that presuppose or respond to a prior speech act (e.g. ask a question - answer, claim refute, deny). The concept of answering forms a conceptual network which is similar in English and Swedish but contrasts with respect to the way meanings are divided up between various verbs. English has several verbs of answering, which all have complex networks of meanings, as shown by Rudzka-Ostyn (1995) in her detailed study of the verbs answer, reply, respond, rejoin and retort. The English verbs of answering share a single Swedish verb svara as a major correspondent. This verb has several derived forms that partly have other correspondents than the English verbs of answering, but are organized around underlying conceptual structures that are closely related: försvara 'defend', ansvara (för) 'be responsible (for)' and motsvara 'correspond'.

\subsection{Schemas and frames}

Asking questions is closely related to giving answers. In discourse analysis, question and answer are regarded as a basic type of adjacency pair. As a verbal communication verb used to report speech, answer is special since it presupposes very strongly a question, even if it is not always explicit in the context as in (51) and (52).

(51) I asked him why he and Sarah have no children, and he answered: "Because I've never had the urge to play God."(MW1)

(52) I remember when he was asked what the principal crop of Thailand was and he answered transistor radios. (JB1)

In Rudzka-Ostyn's (1995) analysis, the conceptual networks of the verbs of answering are organized around two schemas. The prior-subsequent schema accounts for the requirement of a prior act, but is rather general. For example, it is one of the preconditions for the relation between cause and result. The correspondence schema accounts for the close relationships between specific elements of the prior act and specific elements of the response. In straightforward examples such as the ones above, the reason given in the answer in (51) 
corresponds to "why" in the question and in (52) "transistor radios" provides the missing information in the question ("what").

In FrameNet, the verbs of answering evoke the frame Communication_response. This frame inherits the structure of the more general Response frame, which is defined as follows: "An Agent performs a Response action in consequence of a Trigger event." 7 The Trigger corresponds to the prior act in the prior-subsequent schema, but is more specific in a way that is specified in the correspondence schema. Table 15 shows the model adapted from FrameNet that will be used for the analysis in this paper. (Note that the frame elements can be realized in any order. The linear arrangement has been specially tailored for expository purposes only.)

Table 15: The Communication Response frame

\begin{tabular}{|c|c|c|c|c|c|c|}
\hline \multirow[t]{2}{*}{ Response frame: } & \begin{tabular}{|l} 
Trigger \\
\end{tabular} & Agent & \multicolumn{3}{|c|}{ Response action } & \\
\hline & $\downarrow$ & $\downarrow$ & $\downarrow$ & & & \\
\hline \multirow[t]{2}{*}{$\begin{array}{l}\text { Communication } \\
\text { Response frame }\end{array}$} & \begin{tabular}{|l|} 
Implicit verbal \\
Trigger
\end{tabular} & Speaker & Speech act & Addressee & Message & Trigger \\
\hline & $\begin{array}{l}\text { QUESTION } \\
\text { QUESTION } \\
\text { QUESTION } \\
\text { ACCUSATION }\end{array}$ & $\begin{array}{l}\text { Peter } \\
\text { Peter } \\
\text { Peter } \\
\text { Peter }\end{array}$ & \begin{tabular}{|l} 
answered \\
answered \\
didn't reply \\
answered
\end{tabular} & me & that he was tired & $\begin{array}{l}\text { my question } \\
\text { to the question } \\
\text { the accusation }\end{array}$ \\
\hline
\end{tabular}

Since the analysis will be based only on sentences containing the verb of answering and its arguments, the Trigger will often be implicit as indicated in the column to the left in Table 15. In some examples from the ESPC as in (51) and (52) above, the Trigger appears in the previous discourse, but it seems as if the Trigger must be pragmatically derived from context in many of the examples from the corpus. The Trigger can also be realized as an argument of the verb, variously realized as a direct object after answer (He didn't answer my question) or as a prepositional object after reply (He didn't reply to my question). Such arguments always point back to the previous context, which must contain an explicit or implicit Trigger for the text to be coherent.

\subsection{The English verbs of answering}

There are only 72 occurrences of answer as a verb in the ESPC, but the examples accounted for in Table 16 suffice to show the most frequent uses.

In the majority of cases, the Trigger is a prior utterance and svara is used as a Swedish translation. One difference is that the Trigger is realized as a direct object in English when it is explicitly mentioned, whereas it requires the preposition $p a ̊$ 'on' as a marker in Swedish (see 53).

7 The definition continues: In many cases, a non-agentive Responding_entity causes the Response after the Trigger occurs. The definition of the Communication_response frame runs: This frame deals with a Speaker communicating a reply or response, a Message, to some prior communication or action, the Trigger. 
(53) Rather than answer this question, Marjorie reverts to an earlier one.(DL1)

Istället för att svara på frågan återgår Marjorie till den tidigare.

Table 16: The uses of answer and its major translations in the ESPC

\begin{tabular}{|c|c|c|c|c|c|c|}
\hline English answer & & & Swedish translations & & & \\
\hline Trigger: & & $\mathrm{N}$ & & & & \\
\hline PRIOR UTTERANCE & & 39 & svara & 33 & besvara & 3 \\
\hline PRIOR UTTERANCE: & as object & 14 & svara på & 5 & besvara & 8 \\
\hline PRIOR UTTERANCE: & Contested & 3 & säga emot & 2 & ge svar på tal & 1 \\
\hline PRIOR UTTERANCE: & Critical & 3 & bemöta 'meet' & 3 & & \\
\hline PHONE SIGNAL & & 6 & svara & 4 & & \\
\hline DOOR SIGNAL & & 3 & $\begin{array}{l}\text { öppna dörren 'open the } \\
\text { door' }\end{array}$ & 3 & & \\
\hline WISH & & 1 & bönhöra ‘hear a prayer’ & 1 & & \\
\hline CRIME & & 1 & lösa 'solve' & 1 & & \\
\hline $\begin{array}{l}\text { REPREHENSIBLE PRIOR } \\
\text { ACT }\end{array}$ & & 2 & $\begin{array}{l}\text { stå till svars } \\
\text { 'stand to answern' }\end{array}$ & 2 & & \\
\hline TOTAL & answer & 72 & svara & 42 & & \\
\hline
\end{tabular}

As an alternative, the Trigger can be realized as a direct object also in Swedish by using besvara, which is a form of svara derived with the applicative prefix be- (see 54).

(54) He was a genial soul, very ready to talk and to answer any questions I asked him.(OS1)

Han var en sympatisk själ som gärna pratade och besvarade allehanda frågor jag ställde till honom.

There are some examples where the Swedish translation incorporates special aspects of the meaning signaled by answer used in special constructions or used in special contexts. Examples (55) and (56) show translations of answer used as a phrasal verb answer back that signals that the Trigger contains contested information. Säga emot (lit. 'say against') and ge svar på tal ('give answer on speech') can be used to express the corresponding meanings in Swedish.

(55) Never answer her back.(RD1)

Säg aldrig emot henne. [say never against her]

(56) only Abe never sulked, he had the gift of the gab, he answered back,(MD1)

han var begåvad med en rapp tunga, han gav svar på tal, [gave answer on speech]

Another translation tied to a specific context is bemöta (a prefixed form of möta 'meet') combined with an abstract noun. This translation is used when the Trigger contains criticism that is rejected as in (57).

(57) I had designed them to answer the criticism of Ford Doolittle and Richard Dawkins that Gaia was teleological.(JL1)

Jag gjorde den för att bemöta den kritik jag hade fått från Ford Doolittle och Richard Dawkins /---/

As demonstrated by (58), this type of translation is not tied to the translation of any specific abstract noun such as criticism but can be used as soon as the semantic criterion is satisfied. 
(58) I cannot say the same, however, for her unwelcome slurs on my colleague Mr Elles, particularly as he is not here to answer them.(ECHI1)

/---/ i synnerhet eftersom han inte är närvarande för att bemöta dem.

Very specific is the translation when the Trigger refers to a prayer as in (59), where Swedish uses a compound verb as translation: bönhöra (bön 'prayer' + höra 'hear').

(59) And then, miraculously, her prayer was answered.(PDJ1)

Sedan blev hon på ett mirakulöst sätt bönhörd.

The Trigger can also be some kind of non-verbal signal. English and Swedish are similar when the Trigger is a phone signal (see 60).

(60) Många signaler gick fram innan fru Wallin svarade.(HM2)

The phone rang for some time before the widow answered.

When the signal comes from the door bell (or a knock on the door), Swedish uses the expression (gå och) öppna '(go and) open' as in (61).

(61) She'd answered the door.(RDO1)

Hon hade öppnat dörren.

Table 17 shows the translations of all the verbs of answering in English. (correspond has been added since it will be discussed in Section 6.3.)

Table 17: Translations of the English verbs of answering in the ESPC

\begin{tabular}{lcccccc}
\hline English verb & answer & reply & respond & retort & rejoin & correspond \\
\hline Total & 72 & 57 & 30 & 1 & 0 & 21 \\
$\begin{array}{l}\text { Translations: } \\
\text { svara }\end{array}$ & 44 & 47 & 9 & 1 & & \\
besvara & 11 & 1 & & & \\
ge svar ${ }_{\mathrm{N}}^{\text {'give answer' }}$ & 5 & & & & & \\
motsvara & & & & & & \\
säga 'say' & 2 & 5 & 1 & & & \\
reagera 'react' & 10 & 4 & 12 & 0 & 0 & 2 \\
Other & & & & & & \\
\hline
\end{tabular}

The verb reply usually describes the response to a question as trigger and is translated with svara in the majority of cases (47 out of 57). In a high proportion of the examples (39 out of 57), the Message is realized as a direct report (see 62).

(62) He had instantly replied, "No, Your Majesty."(ST1)

Han hade omedelbart svarat: "Nej, Ers Majestät."

The presence of a direct report makes it natural to use säga 'say' as a translation of reply in 5 examples (see 63). However, this is a rather small proportion of the total number of examples.

(63) “That so, Evvie?” George replied since some reply seemed necessary.(SK1)

"Jaså du, Evvie", sa George Meara eftersom hon verkade vänta sig ett svar. 
The verb respond is also used as a verbal communication verb with svara as a translation (see 64), but this rather represents a special use of the verb in certain contexts. Its meaning should probably be connected directly to the general response frame, since the Trigger in many cases is non-verbal. Swedish svara can be used even in such cases (see 65), but the most frequent translation is reagera 'react' (see 66).

(64) And so would he, responded Alexander, were he not Alexander.(JH1)

Och det skulle han också göra, svarade Alexander, om han inte vore Alexander.

(65) they [the Americans] responded coolly and decisively to the Mortain assault.(MH1) Amerikanerna svarade kyligt och beslutsamt på angreppet vid Mortain.

(66) Usually they'll respond to treatment.(AH1)

I vanliga fall reagerar de på behandling.

Note that the usual marker of the trigger is used in the last two examples (to in English and $p a$ 'on' in Swedish). It can also be remarked that svara can be used as a translation of react in many cases, in spite of the fact that the trigger is non-verbal as in (67).

(67) I reacted with one of those little jumps you do when you open the evening paper and a spider runs out. (SG1)

Jag svarade med att hoppa till på det sätt som man gör när man öppnar kvällstidningen och en spindel kilar fram.

There is only one example of retort in the ESPC (see 68) and rejoin only appears once as a translation of svara (in a Swedish original, see 69). According to Rudzka-Ostyn (1995), these two verbs tend to express disagreement with a prior utterance, but this is not clearly reflected in the few examples in the ESPC. Nevertheless, these examples show the great range of correspondents to svara, when it is used as a verbal communication verb.

(68) Perhaps he'd like to retort: "I like you too"?(BR1)

Kanske skulle han vilja svara: "Jag tycker om er också"?

(69) - Då halshugger man oss, svarade han buttert.(KOB1)

"If we did, they'd chop our heads off," he rejoined sullenly.

Actually, there are a few rather infrequent verbal communication verbs with a specialized meaning that can serve as alternatives to svara in Swedish such as genmäla in (70) och replikera in (71).

(70) Kronprinsen måste skyddas, hade Rantzau då kyligt genmält eftersom han inte fann att detta var ägnat för skämt.(MPC:POE2)

"The Crown Prince must be Protected," Rantzau retorted coldly, since he didn't find it a suitable topic for jest.

(71) "Det säger du varje år", replikerade Birger.(MPC:KÖ)

"You say that every year," replied Birger. 


\subsection{Swedish svara and its derived forms}

Interestingly, Swedish svara is etymologically related to answer. According to OED, answer has developed from Old English swęrian 'to affirm, swear' in combination with ant- 'against' and the original meaning was a solemn affirmation made to rebut a charge. In present-day Swedish, there is an umlauted form svära derived from svara. Like it English cognate, svära 'swear' can mean both 'to curse, use bad language' and 'take an oath'. The degree to which answer and svara still correspond semantically in present-day Swedish can be observed in Table 18, which shows the translations of svara in various uses.

Table 18: Translations of the Swedish verb svara

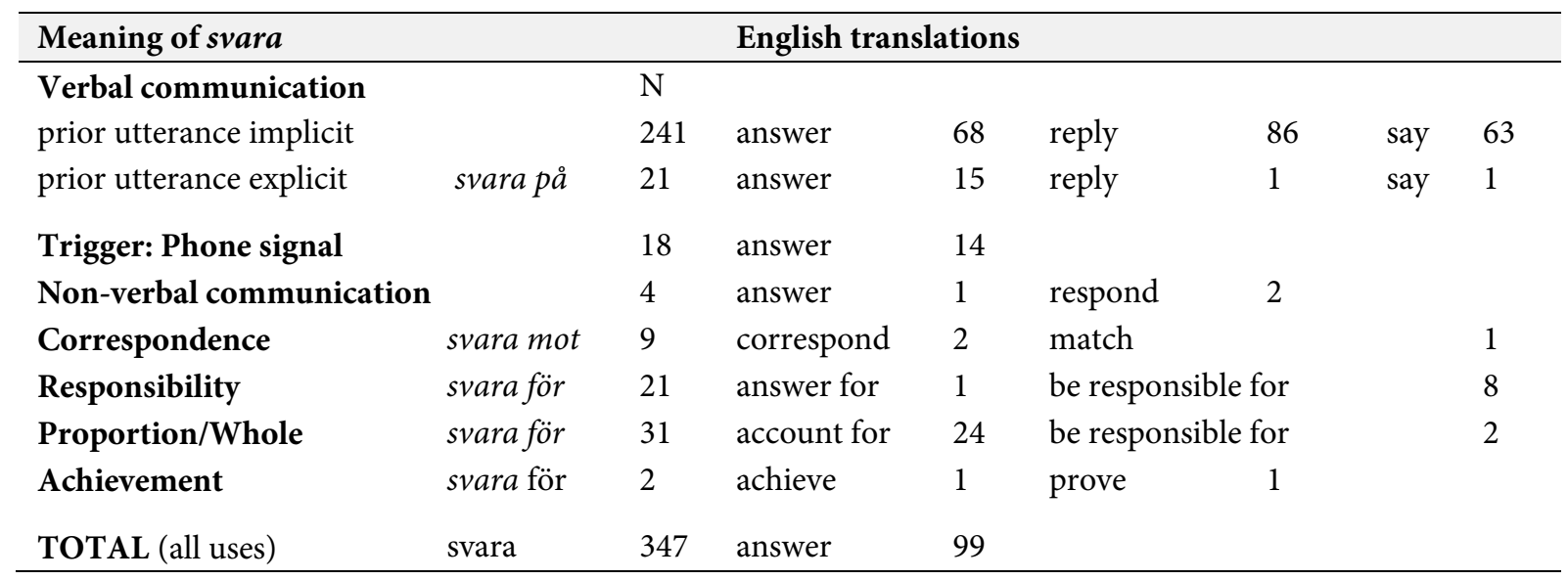

In the majority of cases, svara is used as a verbal communication verb with an implicit Trigger. (Note that "implicit" indicates that the Trigger is not included in the argument structure of svara. It may be explicit in the previous discourse). The most interesting result is that reply and in particular say are used as translations besides answer to such a great extent. Swedish säga is used only a few times as translation of answer and reply as mentioned above. The use of reply and say is conditioned by the use of a direct report as demonstrated in Table 19.

Table 19: Message of svara realized as a direct report

\begin{tabular}{lcccc}
\hline Trigger: Prior utterance implicit & \multicolumn{4}{c}{ Translations } \\
\hline \multirow{4}{*}{ Total } & answer & reply & say \\
& 241 & 68 & 86 & 63 \\
Direct report & 25 & 62 & 56 \\
No message & 36 & 15 & 0 \\
\hline
\end{tabular}

The use of reply reaches a high frequency only in fiction and this appears to be related to the frequent use of dialog and direct report in that register. The use of say has a parallel in the use of säga as a frequent translation of tell in translations from English into Swedish and in a significant underrepresentation of tell in English texts translated from Swedish. (Säga appears to be translated with say in contexts where tell could have been used. See Viberg 2016.) Another noteworthy feature is that answer is preferred when there is no explicit message (e.g. Peter answered. / Peter didn't answer.) Answer is also the preferred translation when there is 
an explicit Trigger in Swedish (see the second line from the top in Table 18). As mentioned, $p a ̊$ 'on' is required as a marker after svara, whereas the Trigger is realized as direct object in English. Reply is more marked and requires a preposition: He didn't reply to the question. Another case where answer is the preferred translation is when the Trigger is a phone signal. Closely related is the use of svara when it refers to other types of Non-Verbal communication. In one of the four examples of this type, answer is used as a translation: han svarade med ett litet flin:(AL1), translated: he answered with a little grin. Respond appears as a translation of two more such examples, e.g.: Jag svarade med en gest.(BL1) I responded with a similar gesture.

The meanings of svara discussed so far have all be concerned with (symbolic) Communication. Svara also has a number of uses where it refers to other types of meanings. In these uses it is characteristically combined with a specific preposition as indicated in Table 18. A further option is to use one of the derived forms of svara. The major translations of the derived forms, which are shown in Table 20, give an idea of their basic meanings.

It is often possible to alternate between a certain derived form and one of the combinations of svara with a preposition. The derived forms have a tendency to be somewhat more formal and/or have a more abstract meaning. The first alternation of this type has a grammatical function. As mentioned, the Trigger cannot appear as the direct object of svara but must be marked with the preposition $p a ̊$ 'on' as in (72).

(72) Men du svarade inte på frågan. (JG1)

But you didn't answer the question.

Table 20: Translations of the Swedish verb svara and its derived forms

\begin{tabular}{lccccc}
\hline & & Promotion to direct object & Responsibility & Correspondence & Defense \\
\hline Swedish verbs & svara & besvara & ansvara för & motsvara & försvara \\
\hline TOTAL & 347 & 18 & 12 & 55 & 32 \\
Translations: & & & & & \\
answer & 99 & 11 & & & \\
reply & 88 & & & & \\
say & 64 & & & & \\
account for & 24 & & & & \\
defend & 0 & & & & \\
be responsible & 11 & & & & \\
correspond & 2 & 7 & 11 & & \\
OTHER & 59 & & & & \\
\hline
\end{tabular}

The Trigger can be promoted to object by substituting the prefix be-for the preposition $p a$ : Du besvarade inte frågan 'You didn't answer the question'. Unlike svara $p a ̊$, the prefixed form besvara can be passivized (see 73). Such forms are found in particular in Non-Fiction. The most frequent translation of besvara is answer, which also takes the Trigger as a direct object that can be passivized.

(73) högar av brev skall besvaras och många besök förberedas.(GAPG1) piles of letters need to be answered and many calls must be prepared. 
In Swedish, the verb försvara (sig) 'defend (oneself)', which consists of svara and the unstressed prefix för-can be used both as a verbal communication verb and with reference to physical or military defense. Example (74) conceptually is closely related to the response frame. The accusation serves as a trigger for the verbal defense.

(74) I natt i drömmen kort samtal med Ruth B. Hon tycktes anklagande: jag försvarar mig häftigt.(PE1)

At night in the dream short talk with Ruth B. She appears to accuse me: I defend myself violently.

The message can even be realized as a direct report as in (75), where the general communication verb say is used as a translation.

(75) - Men om dom står på vinden, är det ju ingen som använder sakerna, försvarade sig pojken.(MR1)

"But if they're in the loft, no one uses the things," the boy had said in his defence.

The message can also be realized as an indirect report, which expresses a justification (see 76). A special construction is used: försvara (sig) med att-S. (med is an instrumental preposition).

(76) Berra försvarade oss med att det kunde ju hända att Janne mådde pyton, så han kunde behöva hjälp rätt vad det var.(PP1) [defended us with that-S]

Bert claimed we were doing the right thing cos for all we knew Johnny wasn't feeling too good, and he might need a bit of help all of a sudden.

In (77), försvara appears in a context where it refers to physical defense.

(77) Väine blev mer och mer irriterad när Johan duckade utan att försvara sig.(KE1)

Väine grew more and more annoyed when Johan ducked without defending himself.

As a verbal communication verb, correspond and its Swedish cognate korrespondera can refer to an exchange of letters: Peter corresponded with Maria - Peter korresponderade med Maria. In this use, correspond refers to an activity and is constructed like a speech activity verb (cf. Peter conversed with Maria, see Viberg 2016, Section 4). There is no example of this use in the ESPC corpus, but only abstract examples which have a meaning that is closely tied to the correspondence schema: two entities have parts or characteristics that are related to one another or fulfill complementary roles (like Speaker and Addressee in the Communication frame. In example (78), "sparks" and "lightning" are related in this way. Note that a different preposition (to) is used when correspond is used with this meaning.

(78) The sparks correspond to lightning - also present on the ancient Earth and on modern Jupiter.(CSA1) Gnistorna motsvarar blixtar — som också fanns i den urtida jordatmosfären och finns på dagens Jupiter.

The correspondence schema plays an important role in Rudzka Ostyn's (1995) analysis of the verbs of answering. The centrality of this schema is supported by the fact that the major translation of the English verb correspond is the derived form of svara, namely motsvara as in (79).The derived form alternates with the combination of verb + preposition: svara mot (mot 'towards, against'). Compare examples (79) and (80).

(79) Uttaget av virke motsvarar 79\% av tillväxten på brukad skogsmark.(ASSI1)

Timber extraction corresponds to $79 \%$ of growth on cultivated land. 
(80) Detta förutsätter, att samhället genom beskattning av inkomster och förmögenheter kan omfördela resurser i den omfattning som svarar mot dessa sociala behov.(SOC1)

This presupposes an ability on the part of society, through the taxation of incomes and wealth, to reallocate resources to the extent corresponding to these social needs.

When the correspondence is exact in some respect, the verb överensstämma can be used in Swedish as in (81).

(81) The wounds to the wrists correspond precisely with the Stanley knife blade discovered on the bathroom floor,(MW1)

Såren på handlederna överensstämmer exakt med gipskniven som påträffades på badrumsgolvet,

Figure 2 shows how svara and its derivatives are related conceptually via the PriorSubsequent and Correspondence schemas.

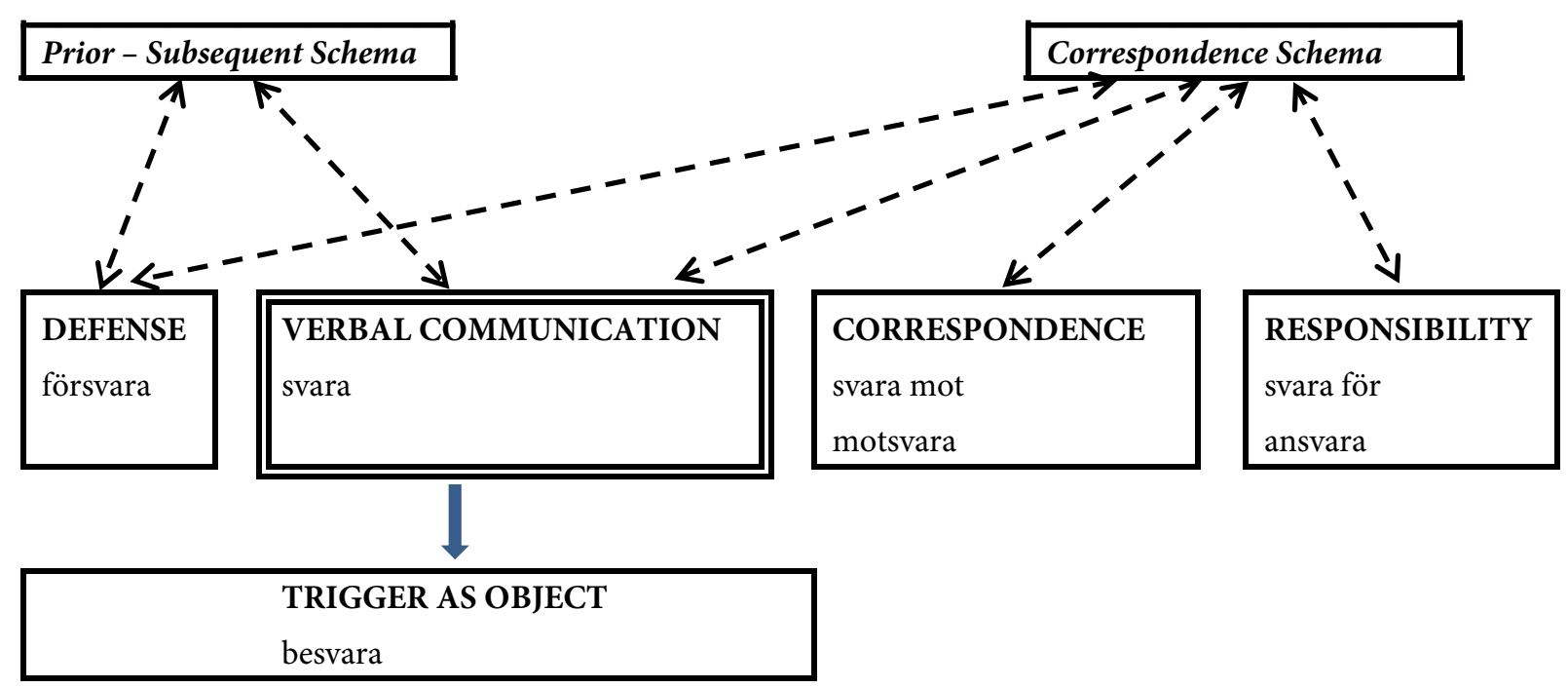

Figure 2: The relationships between the major meanings of the verb stem svara 'answer' and conceptual schemas

In its most prototypical use, svara is related to a question which must be prior to the answer. In addition, there must also be a correspondence at a more detailed level between the information asked for and the information given (in the ideal case). The frame element Trigger, which plays a prominent role in the Response frame in FrameNet, also must be prior and in addition must correspond in crucial ways to the response. If the last condition is not fulfilled, the prior element could be of a more general type, for example any type of Cause. As an answer to an attack (or an accusation), a defense depends both on the attack being prior to the defense and on a correspondence between this specific type of trigger ('hostility') and the specific type of answer. Correspondence, on the other hand, is a static relationship, and is not related to the Prior-Subsequent schema. The same applies to Responsibility, as will be demonstrated shortly. The arrows showing the connections are bidirectional. When they go from the schema, they indicate an instantiation of the schema. The opposite direction indicates abstraction. The connection between svara and besvara (Trigger as Object) is symbolized with a solid arrow which indicates a morphological relation (prefixation).

When svara refers to Responsibility, there is an alternation between svara för lit. 'answer for' (see 82) and ansvara för (see 83) (cf. the noun ansvar 'responsibility' and the adjective 
ansvarig 'responsible'). Different domains of responsibility are related to (correspond to) various responsible parties. This is particularly clear in (83). Thus, the Correspondence schema is relevant also for Responsibility, but the relation is completely static, so the PriorSubsequent schema is not relevant. The major English translation is be responsible for. In addition, be in charge of is used in one example.

(82) Arbetsgivare och arbetstagare svarar gemensamt för att skyddsombud får erforderlig utbildning. Lag (1991: 677).(ARBM1)

Employer and employees are jointly responsible for safety delegates being given the requisite training.

(83) Hans Quiding ansvarade för vissa delar, Viking Göransson för andra och Nils Einar Eriksson för den enorma festplatsen med hela restaurangen.(CE1)

Hans Quiding was responsible for some parts, Viking Göransson for others and Nils Einar Eriksson for the enormous festival square and the entire restaurant.

Svara för, but not ansvara, has another meaning, where the verb refers to amounts that form part of a larger sum (the WHOLE). The relationship between part and whole might be regarded as an instantiation of the correspondence schema. (This is not completely obvious and would deserve a deeper analysis, but that falls outside the scope of this paper on verbal communication). (84) is based on an actual example in the ESPC (word order has been normalized).

$\begin{array}{llllll} & & & \text { PART: amount } & & \text { WHOLE: sum } \\ \text { Steamers } & \text { accounted } & \text { for } & 33 \text { million kronor } & \text { of } & \text { this sum } \\ \text { Ångfartygen } & \text { svarade } & \text { för } & 33 \text { miljoner kronor } & \text { av } & \text { detta belopp }\end{array}$

Be responsible for is used as a translation even of this meaning of svara för (see 85).

(85) A small group of people on long-term sick leave are responsible

[for a very large proportion]PART

[of the total number of days of sick leave]WHOLE

En liten grupp av långtidsfrånvarande svarar för en mycket stor del av antalet sjukfrånvarodagar.(ARB1)

\section{Conclusions}

The verb ask is interesting because it has a number of different meanings, each of which appear in specific types of constructions that serve as cues for the interpretation, when the verb appears in different contexts. The two basic Swedish correspondents fråga and be not only correspond to the two different semantic prototypes of ask (ask $k_{\text {Question }}$ and $a s k_{\text {Request }}$ ) but also divide up the constructions in which they appear in a parallel way. The verbs of answering in English are interesting primarily because they form a network together with other English verbs conceptually organized around the Response frame. In Swedish, large parts of this network are expressed lexically in words that are morphologically derived from the verb svara 'answer'. Thus the conceptual network is reflected to a great extent in the morphological relatedness between word forms. 
The analysis in this paper is presented from a theoretical perspective but also represents a good point of departure for teaching the basic contrasts. Most of the senses described in this paper and often also a number of less frequent ones can be found in a good comprehensive dictionary. However, for reasons of space and due to the alphabetical organization, which is convenient for looking up words, words and their senses are listed without explaining how they contrast with semantically related words and how various uses are related to the general structure of the language.

This study of the verbs ask and answer together with the parallel study of the verbs say, tell, speak and talk compared with their Swedish correspondents (Viberg 2016) show how the basic semantic contrasts within the field Verbal Communication are expressed across the two languages departing from shared basic elements in the conceptual structure such as Speaker, Linguistic action, Addressee, Message and Topic. When these elements are realized syntactically the Speaker is canonically realized as Subject, whereas the Addressee variously is realized as an Object or a PP depending on the verb, for example I answered her, I talked to her. In Swedish, the Addressee is also realized as an object after svara (Jag svarade henne) but as a PP with the preposition med 'with' after prata 'talk'; Jag pratade med henne. (With is possible also in English but represents a marked alternative). The verb tell also takes the Addressee as an object: I told her the result, whereas the Addressee is marked with the preposition för 'for' when it appears after the Swedish correspondent berätta: Jag berättade resultatet för henne. The Topic is usually marked with about in English and om in Swedish: I talked about her / Jag pratade om henne. These are only some simple examples, but it is possible to present, for example, some of the more complex realizations of the Message in similar ways.

\section{References}

Altenberg, B., and K. Aijmer. 2000. The English-Swedish Parallel Corpus: A Resource for Contrastive Research and Translation Studies. In C. Mair, and Ma. Hundt (eds.), Corpus Linguistics and Linguistic Theory, 15-23. Amsterdam and Atlanta: Rodopi.

Dirven, R., L. Goossens, Y. Putseys, and E. Vorlat. 1982. The Scene of Linguistic Action and its Perspectivization by Speak, Talk, Say and Tell. Amsterdam: Benjamins.

Fillmore, C.J. 1982. Frame Semantics. In Linguistics in the Morning Calm, edited by The Linguistic Society of Korea, 111-138. Seoul: Hanshin Publishing.

Fillmore, C.J., C.R. Johnson, and M.R.L. Petruck. 2003. Background to FrameNet. In T. Fontenelle (ed.), FrameNet and Frame Semantics, Special issue of International Journal of Lexicography 16: 231-366.

Hammarberg, B., and A. Viberg. 1976. Reported Speech in Swedish and Ten Immigrant Languages. SSM Report 5. Department of Linguistics, Stockholm University. Available at: http://www.ling.su.se/polopoly_fs/1.14093.1320939586!/SSM_05_1976.pdf.

Harras, G., E. Winkler, S. Erb, and K. Proost. 2004. Handbuch deutscher Kommunikationsverben. 1. Wörterbuch. Berlin: de Gruyter.

Harras, G., K. Proost, and E. Winkler. 2007. Handbuch deutscher Kommunikationsverben 2. Lexikalische Strukturen. Berlin: de Gruyter.

Johansson, S. 2007. Seeing through Multilingual Corpora. Amsterdam: Benjamins.

Proost, K. 2007. Conceptual Structure in Lexical Items. Amsterdam: Benjamins.

Rudzka-Ostyn, B. 1989. Prototypes, Schemas and Cross-Category Correspondences: The Case of ask. Linguistics 27: 613-661. 
Rudzka-Ostyn, B. 1995. Metaphor, Schema, Invariance: The Case of Verbs of Answering. In L. Goossens, P. Pauwels, B. Rudzka-Ostyn, A.-M. Simon-Vandenbergen, and J. Vanparys (eds.), By Word of Mouth, 205243. Amsterdam: Benjamins.

Searle, J.R. 1976. A Classification of Illocutionary Acts. Language in Society 5: 1-23.

SUC 1.0. 1997. The Stockholm Umeå Corpus. Produced by Dept. of Linguistics, Umeå University and Dept. of Linguistics, Stockholm University. CD ROM.

Viberg, Å. 2008. Swedish Verbs of Perception from a Typological and Contrastive Perspective. In M. de los Ángeles Gómez González, J. Lachlan Mackenzie, and E.M. González-Álvarez (eds.), Languages and Cultures in Contrast and Comparison. [Pragmatics and Beyond New Series 175], 123-172. Amsterdam: Benjamins.

Viberg, A. 2015a. Contrasts in Construction and Semantic Composition: The Verbs of Putting in English and Swedish in an Intra-Typological Perspective. In H. Hasselgård, and S. Oksefjell Ebeling (eds.), Crosslinguistic Perspectives on Verb Constructions [Studies in Language and Translation Series], 222-253. Newcastle upon Tyne: Cambridge Scholars Publishing.

Viberg, A. 2015b. Motion Verb Typology and the Expression of the Endpoint of Motion in Swedish. In M. BlochTrojnar, A. Malicka-Kleparska, and K. Drabikowska (eds.), Concepts and Structures - Studies in Semantics and Morphology. Studies in Linguistics and Methodology (SLAM), 209-229. Lublin: Wydawnictwo KUL.

Viberg, A. 2016. SAYING, TALKING and TELLING. Basic Verbal Communication Verbs in Swedish and English. [Publication from ICAME 36. Trier 2015. To be specified.]

\section{Electronic sources}

FrameNet: http://www.icsi.berkeley.edu/ framenet/ The Bank of Swedish: http://spraakbanken.gu.se/eng The English Swedish Parallel Corpus (ESPC): http://www.sol.lu.se/engelska/corpus/corpus/espc.html 